\title{
A Psychological Content of the Conflict Behaviour of Young Adolescents
}

\section{Психологічний контент конфліктної поведінки підлітків}

\author{
Natalia Tokareva \\ Dr. in Psychology, Assistant \\ Professor, Head of the \\ Department of General \\ and Age-related Psychology
E-mail: tokareva152681@gmail.com orcid.org/0000-0003-1428-3729
Researcher ID: G-8396-2019

Наталя Токарева

доктор психологічних наук, доцент, завідувач кафедри загальної та вікової психології

\begin{abstract}
Kryvyi Rih State Pedagogical University, Kryvyi Rih, Ukraine 54, Gagarin av., Kryvyi Rih, Криворізький державний педагогічний університет, Dnipropetrovsk region, 50086 пр. Гагаріна, 54, м. Кривий Ріг, Дніпропетровська обл., 50086

Original manuscript received April 11, 2019 Revised manuscript accepted April 30, 2019
\end{abstract}

\begin{abstract}
The article presents the findings of a study of the psychological content of the destructive behaviour of young adolescents in terms of inconstant information society. It is proved that under the conditions of acceleration of the pace of the modern history and the development of the information society, a need arises to rethink the subjective indicators of the personality-related maturing of a child. It is stated that the accents are shifting in the direction of the development of critical thinking, ingenuity, creativity, self-sufficiency and flexibility of the formation of logical patterns of behaviour. The skills of shaping
\end{abstract}


constructive interpersonal relationships are identified as the most significant achievement of the child's personality development in the age of information progress.

The author states the most sensitive to the variability of the social environment are those teenagers, whose risks of destructive and, in particular, conflict forms of behaviour are on the increase, on the background of the manifestations of the age-specific crisis of development. It is established that the phenomenon of bulling (harassment) as a deliberate, systematically recurrent aggressive form of behaviour based on the social inequality and / or the inequality of physical force is common among young adolescents. It is proved that teenage bulling and destructive forms of schoolchildren's behaviour in the period of transition to adulthood acquire the signs of instrumental aggression, and are a variety of protection from the disrespect to personality.

The author describes the results of the research devoted to modern adolescents' behavioral strategies in conflict situations. It was empirically investigated the substance structure of the personological profile of the propensity for conflict and adolescent aggressiveness. It is established that the most significant personality characteristics of the complex of symptoms of aggressiveness and the propensity for conflict in young adolescents are uncompromising attitude and irascibility; in the complex of aggressiveness, positive aggressiveness prevails, which is characterized by such distinctive features of behaviour as offensiveness and intransigence.

The conclusion is drawn that the purpose of teenagers' conflict is mainly to upset the psychological balance of opponents and to assert oneself, which is explained by the lack of experience in constructive behaviour and dialogic communication skills. It is stated that modelling optimum personality constructs in adolescence is possible only in the context of acquiring personal experience of successful rational-constructive behaviour and enhancing the psychological culture of dialogic partnership.

Key words: adolescent, personality profile, psychological resource, conflict, conflict behavior, behavioral strategy, conflict situation.

\section{Вступ}

Полімодальність розвитку суспільства у вимірах XXI століття ставить перед особистістю складні завдання переосмислення контекстуальної програми самореалізації. Руйнація усталених стереотипів світосприймання, множинність конфігурацій спілкування у мультикластерних мережах Internet-простору, невизначеність схем життєтво- 
рення й ризики прийняття відповідальних рішень вносять суттєві корективи у загальноприйняті моделі становлення особистості у несталих умовах буття; у цьому контексті відбувається переосмислення суб'єктивних індикаторів дорослішання особистості. Акценти зміщуються у напрямах розвитку критичного мислення, творчої винахідливості, креативності, самостійності, гнучкості утворення логічних схем поведінки (Лисенко, 2002; Токарева, 2015; Шамне, 2015). Проте науковою спільнотою найдоцільнішим надбанням особистісного розвитку дитини в епоху інформаційного прогресу вважаються навички вибудовування конструктивних міжособистісних стосунків. Адже смисл існування особистості (у контексті екзистенційної філософіï) визначають стосунки з Іншими Я (alter Ego), котрі є фрактами феноменологічної сфери людської сутності; взаємодія з Іншими - це умова існування особистості, що забезпечує можливість самопізнання й, водночас, можливість вийти за межі свого існування, прийняти своє «буттядля-Іншого» і через нього - себе як «абсолютну цінність», стати цілісною особистістю й осягнути сенс свого існування. Особливо актуальними означені тенденції є у підлітковий період ґенези буття, упродовж якого інтимно-особистісне конгруентне спілкування виконує функцію провідної діяльності та, разом із тим, на тлі проявів вікової кризи розвитку зростають ризики деструктивних, конфліктних форм поведінки. Для підлітків система міжособистісних стосунків виступає полем постійного зіткнення, пов'язаного зі з'ясуванням особистісних проблем і самоствердженням. Підлітки вдаються до конфліктної поведінки й бунтарства як до основного способу досягнення автономії від дорослих (Білик, 2017; Резнікова \& Солодка, 2018).

Численні дослідження поведінкових патернів підлітків засвідчують нестійкість, агресивність поведінки особистості у період дорослішання, що пов'язано, переважно, з низьким рівнем комунікативної культури (Bochaver, Zhilinskaya \& Khlomov, 2015; Токарева, 2015), відсутністю 
навичок адаптивного реагування на конфліктні ситуації (Леонов, 2002; Гіренко, 2014; Резнікова \& Солодка, 2018), недостатнім рівнем розвитку толерантності свідомості (Лисенко, 2002; Гіренко, 2014) трансформаційного суспільства загалом (Бочавер \& Хломов, 2013: 152). Поширення неадаптивних (конфліктних) моделей поведінки у системі освіти руйнує схеми гармонійного форматування персонологічного профілю суб'єктів навчально-виховного процесу (Токарева, 2018), шкодить психічному здоров'ю (Ващенко \& Іваненко, 2018), зумовлює розвиток особистісної конфліктності (Ульянова, 2017) суб’єктів освітньої взаємодії. Д. В. Ж゚арова й Е. Ю. Терех однією з основних передумов деструктивної поведінки школярів у освітньому просторі визнають неповагу в ставленні до особистості підлітків (Ж⿱арарова \& Терех, 2018: 79). У підлітковому віці деструктивні форми поведінки набувають ознак інструментальної агресії, є своєрідним різновидом захисту дитини у період дорослішання (Olweus, 1993), а конфліктологічний досвід виступає невід'ємною умовою для формування патернів поведінки людини в різних психологічно складних i напружених стосунках (Гіренко, 2014: 59).

Разом із тим, незважаючи на численні дослідження конфліктних і агресивних сценаріїв поведінки особистості, змістова сутність деструктивної поведінки сучасних підлітків залишається на периферії психолого-педагогічних розвідок.

Зважаючи на практичні запити реформування сучасного освітнього простору, потребу психологічної служби закладів середньої освіти в означенні векторів психологопедагогічного супроводу дорослішання підлітків в умовах несталого середовища, нами було обрано за мету статті розширення уявлень про конфліктну поведінку школярів підліткового віку в умовах несталого інформаційного середовища, а також вивчення потенційних можливостей підвищення психологічної культури діалогічного партнерства підлітків. 


\section{Завдання статті}

Досягнення мети передбачало вирішення низки завдань: 1) дослідити стилі поведінки сучасних підлітків у конфліктних ситуаціях; 2) розглянути базові компоненти персонологічного профілю агресивності й конфліктності підлітків; 3) урахувати специфіку міжстатевої диференціації респондентів при дослідженні змістової структури профілю агресивності й конфліктності підлітків; 4) окреслити корекційний потенціал моделювання конструктивних стратегій спілкування у площині підвищення психологічної культури діалогічного партнерства школярів підліткового віку.

\section{Методи та методики дослідження}

Необхідність перевірки теоретичних положень щодо психологічного контенту конфліктної поведінки підлітків і конфліктності як передумови деструктивної поведінки зумовила логіку проведення емпіричного дослідження.

Базою емпіричного дослідження було обрано загальноосвітні школи I-III ступенів м. Кривого Рогу. Вибірку склали 432 учні віком 11-15 років.

У якості психодіагностичного інструментарію було використано тестові методики «Оцінка способів реагування у конфлікті» (К. Н. Томас; адаптований варіант Н. В. Гришиної) та «Особистісна агресивність і конфліктність» (Є. П. Ільїн, П. А. Ковальов), призначені для виявлення схильності суб'єкта до конфліктності й агресивності як особистісних властивостей; ураховувалися також результати включеного спостереження за поведінковими сценаріями школярів підліткового віку й експертні оцінки поведінкових сценаріїв підлітків вибіркової сукупності вчителями шкіл. Аналізу підлягали способи реагування підлітків у конфліктних ситуаціях, психологічні особливості виявлення особистісної конфліктності, деструктивні поведінкові схеми і сценарії підлітків у навчальній діяльності й у міжособистісній комунікації. 
При узагальненні й аналізі емпіричних матеріалів було використано комп'ютерну статистичну програму IBM SPSS Statistics 19 («Statistical Package for the Social Science»). Змінні було перевірено на нормативність розподілу ознаки.

\section{Результати та дискусії}

Грунтовне вивчення механізмів моделювання особистісних конструктів (Токарева, 2015) у вимірах соціальнокогнітивної теорії (Bandura, 1978) дає підстави констатувати здатність людини упродовж життя засвоювати різноманітні поведінкові патерни й ускладнювати персонологічний досвід реагування на змінні ситуації життєтворення. У цьому контексті поведінка може інтерпретуватися не лише як функція, але й як незалежна змінна, що впливає на особистість. Модель реципрокного детермінізму (reciprocal determinism) А. Бандури доводить, зокрема, що поведінка людини є результатом взаємодії особистісних чинників (у тому числі мислення і пізнавальної здатності), явищ навколишнього середовища і дій самої людини. Відповідно, особистості не є ні безпорадними об'єктами, контрольованими силами оточення, ні абсолютно вільними істотами, котрі можуть робити усе, що їм заманеться (Bandura, 1978: 356-357).

Становлення особистості підлітків у контексті дорослішання реалізується шляхом активного формування особистісних сценаріїв життя і поведінкової культури суб’єктів життєтворення. Важливим чинником, що впливає на поведінку, ускладнює і модифікує процес становлення життєвої позиції особистості у вимірах даного хронотопу, є персонологічний профіль людини - динамічна система особистісних конструктів, що забезпечує, зокрема, здатність «конструктивної та безпечної взаємодії з соціальним середовищем у складних взаємозалежних ситуаціях, регулює власну поведінку при зіткненні з конфліктогенами, забез- 
печує вибір і реалізацію конфліктної стратегії вирішення значущих для людини питань» (Гіренко, 2014: 60-61).

Для аналізу стратегій поведінки сучасних підлітків у конфліктних ситуаціях було використано методику «Оцінка способів реагування у конфлікті» (K. Thomas; адаптований варіант Н. В. Гришиної); діагностичний потенціал цієї методики дав змогу визначити типові форми соціальної поведінки підлітків вибіркової сукупності у ситуації конфлікту (табл. 1.) згідно з двомірною концепцією регулювання конфлікту К. Томаса, основними вимірами якої $€$ наполегливість (зосередженість особистості на власних інтересах) і кооперація (увага особистості до інтересів інших людей).

Таблищя 1 Показники середніх величин типів поведінки у конфліктах підлітків вибіркової сукупності

\begin{tabular}{|c|c|c|c|}
\hline \multirow{2}{*}{$\begin{array}{l}\text { Критерії } \\
\text { Тналізу } \\
\text { пипи } \\
\text { поведінки } \\
\text { особистості } \\
\text { у конфліктах }\end{array}$} & \multirow{2}{*}{$\begin{array}{c}\text { Середні величини } \\
\text { (Мх) виявлення } \\
\text { показників } \\
(\mathrm{N}=432)\end{array}$} & \multicolumn{2}{|c|}{$\begin{array}{c}95 \% \text { довірчий інтервал } \\
\text { для середнього }\end{array}$} \\
\hline & & $\begin{array}{l}\text { Нижній } \\
\text { поріг }\end{array}$ & $\begin{array}{l}\text { Верхній } \\
\text { поріг }\end{array}$ \\
\hline Конкуренція & 6,10 & 5,88 & 6,33 \\
\hline Уникнення & 5,07 & 4,80 & 5,33 \\
\hline Пристосування & 6,63 & 6,36 & 6,89 \\
\hline Співпраця & 5,44 & 5,07 & 5,81 \\
\hline Компроміс & 6,50 & 6,17 & 6,83 \\
\hline
\end{tabular}

Ранжування середніх величин виявлення типів поведінки респондентів у конфліктних ситуаціях дозволило визначити в якості найпредставленіших способів реагування підлітків вибіркової сукупності пристосування $(\mathrm{Mx}=6,63)$ і компроміс $(\mathrm{Mx}=6,50)$, що є цілком адаптивними, проте не завжди оптимальними моделями по- 
ведінки. Вибір підлітками означених стратегій свідчить про їхню готовність поступатися особистісними інтересами на користь конкурента (модель пристосування обрали 27,3\% респондентів (118 осіб)) або про зорієнтованість на досягнення балансу (модель компромісу в якості пріоритетної обрали 20,1\% підлітків (87 осіб)). Водночас значна частина підлітків $(19,4 \%$ (84 особи)) у якості пріоритетної стратегії поведінки у конфлікті обирає стиль конкуренції $(\mathrm{Mx}=6,10)$, демонструючи прагнення задовольняти власні інтереси, ігноруючи інтереси інших людей, готовність до агресивної поведінки відстоювання власних інтересів у конфліктних ситуаціях. Аналіз результатів дослідження також засвідчив, що підлітки у своїй більшості не схильні уникати взаємостосунків у конфліктних ситуаціях (лише 5,6\% респондентів вибіркової сукупності (24 особи) віддають перевагу цій стратегї̈ реагування), а також не готові активно налагоджувати співпрацю у складних ситуаціях взаємодії (лише 10,4\% (45 осіб) досліджуваних обирають такий тип поведінки як пріоритетний). Кррім того, 17,2\% підлітків (74 особи) демонструють несталість поведінкових стратегій у конфліктах і ситуативно користуються доступними моделями соціального реагування, віддаючи перевагу адаптивним і компенсаторним тенденціям. Тож можна констатувати досить активну позицію переважної кількості підлітків у ситуаціях конфлікту, хоча й не достатньо конструктивну, що, у свою чергу, означає необхідність корекційно-розвивального впливу на поведінкові стратегії підлітків у площині кваліфікованого психолого-педагогічного супроводу особистісного становлення.

Співставлення емпіричних даних, що означують стратегії поведінки у конфліктних ситуаціях підлітків різних вікових груп (11-15 років), дає змогу зафіксувати тенденції динаміки конфліктної поведінки респондентів (табл. 2). 
Таблиия 2

Динаміка типів поведінки у конфліктах підлітків різних вікових груп

\begin{tabular}{|c|c|c|c|c|c|}
\hline Вікові групи & $\begin{array}{l}11 \text { років } \\
(\mathrm{N}=43)\end{array}$ & $\begin{array}{c}12 \text { років } \\
(\mathrm{N}=123)\end{array}$ & $\begin{array}{c}13 \text { років } \\
(\mathrm{N}=103)\end{array}$ & $\begin{array}{c}14 \text { років } \\
(\mathrm{N}=108) \\
\end{array}$ & $\begin{array}{l}15 \text { років } \\
(\mathrm{N}=55)\end{array}$ \\
\hline $\begin{array}{l}\text { поведінки } \\
\text { особистості } \\
\text { у конфліктах }\end{array}$ & \multicolumn{5}{|c|}{ Середні величини (Мx) } \\
\hline Конкуренція & 5,93 & 5,10 & 5,76 & 5,49 & 4,50 \\
\hline Уникання & 5,09 & 5,07 & 5,14 & 5,02 & 4,75 \\
\hline Пристосування & 5,84 & 6,89 & 6,07 & 6,60 & 7,37 \\
\hline Співпраця & 5,77 & 6,51 & 5,93 & 5,91 & 5,87 \\
\hline Компроміс & 6,51 & 6,35 & 6,74 & 6,91 & 7,37 \\
\hline
\end{tabular}

Аналіз максимальних показників Мх типів поведінки особистості у конфліктних ситуаціях у віковій динаміці підліткового періоду генези буття засвідчив зниження схильності підлітків до конкуренції (від 5,93 у молодших підлітків до 4,50 у поведінці старших підлітків) і зростання середніх показників таких моделей, як пристосування і компроміс (від 5,84 і 6,51 відповідно у молодшій підлітковій групі до 7,37 у старших підлітків), що пояснюється збільшенням конструктивного особистісного досвіду підлітків у процесі соціалізації особистості. Виявлена тенденція свідчить про інтегрованість у поведінкових сценаріях старших підлітків зосередженості на власних інтересах та уважного ставлення до інтересів інших людей. Водночас динаміка використання стратегії співпраці відзначається деструктивними тенденціями: максимум виявлення $(\mathrm{Mx}=6,51)$ притаманний підліткам 12 років, що свідчить про готовність підлітків цієї вікової групи до активної взаємодії й толерантного ставлення до інтересів інших людей, але надалі спостерігається зниження частотності вибору підлітками зазначеної стратегії $(\mathrm{Mx}=5,87$ у підлітків старшої групи). Однак подальший статистичний 
однофакторний дисперсійний аналіз ANOVA, коректність застосування якого перевірено із залученням критерію однорідності дисперсій Ливіня (при $p>0,05)$, засвідчив, що відмінності між віковими групами у виявленні типів поведінки у конфлікті є статистично не значущими $(p>0,05)$ : Мх порівнюваних величин відрізняються лише кількісно. Отже, у процесі дорослішання динаміка соціальної поведінки підлітків різних вікових груп у ситуації конфлікту $\epsilon$ лише потенційно означеною (кількісною) і не реалізується у якісних статистично достовірних зрушеннях поведінкового профілю суб’єктогенезу. Розмитість поведінкового профілю респондентів вибіркової сукупності свідчить про амбівалентність поведінкових реакцій підлітків у ситуації конфлікту, що детермінує ситуативність зосередженості особистості на власних інтересах та / або на інтересах інших людей.

Кореляційний аналіз із застосуванням коефіцієнта рангової кореляції rs Спірмена виявив зв'язок між віковою групою респондентів і компромісом ( $\mathrm{r}=0,148)$ як способом реагування підлітків у ситуації конфлікту на достатньому рівні статистичної значущості $(p \leq 0,05)$. Виявлений взаємозв'язок є слабким $(0,01<\mathrm{r} \leq 0,29)$, проте означує потенційний напрям (можливість) позитивного розвитку стратегії компромісу в поведінковому профілі підлітків.

Задля уточнення змістовності становлення персонологічного профілю суб'єктів життєтворення, що позначається на стратегіях поведінки у ситуаціях конфлікту підлітків, нами був здійснений аналіз особистісної агресивності й конфліктності як особистісних характеристик підлітків за допомогою методики Є. П. Ільїна і П. А. Ковальова. Ранжування виявлених параметрів особистісної агресивності та конфліктності у вибірковій сукупності підлітків дало змогу виокремити найбільш значущі характеристики досліджуваного симптомокомплексу: безкомпромісність $(\mathrm{Mx}=7,34)$ і запальність $(\mathrm{Mx}=4,97)$. Безкомпромісність тлумачиться як особливість поведінки людини (або риса 
характеру), що позначає непоступливість, ультиматизм, упертість. Запальність розглядається як нестриманість, активна злостивість особистості. Високі рангові позиції цих особистісних характеристик у респондентів дають підстави констатувати амбівалентність особистісних характеристик підлітків: ригідність поведінкових реакцій поєднується з недостатністю самоконтролю, що зумовлює певну неадекватність (деструктивність) вираження власних думок та емоцій у процесі соціальної взаємодії і дезадаптивність поведінкових реакцій.

Співставлення часток позитивної та негативної агресивності у поведінковому профілі підлітків свідчить про відносне домінування позитивної агресивності $(\mathrm{Mx}=8,32)$, показниками якої є такі особливості поведінки, як наступальність і непоступливість. Досить високим є також узагальнений показник загальної конфліктності підлітків $(\mathrm{Mx}=20,67)$, що виражається у безкомпромісності, образливості, мстивості та запальності особистості й свідчить про недостатність сформованості конструктивних сценаріїв поведінки у підлітковому віці.

Подальший аналіз особистісного профілю конфліктності підлітків різних вікових груп (11-15 років) дав змогу прослідкувати основні тенденції вікової динаміки розвитку цих змінних (табл. 3).

Аналіз середніх величин (Mx) виявлення патернів особистісної агресивності й конфліктності у різних вікових групах підлітків зафіксував найбільшу напруженість особистісного профілю молодших підлітків: крива динаміки таких змістових характеристик особистісної агресивності, як уразливість $(\mathrm{Mx}=5,19)$, нетерпимість $(\mathrm{Mx}=4,12)$ і підозріливість $(\mathrm{Mx}=4,62)$ досягає максимуму прояву і відображає суперечливі поведінкові тенденції у молодшому підлітковому віці (11 років). Найпредставленішими у поведінкових сценаріях 11-річних підлітків також є вектори негативної агресивності $(\mathrm{Mx}=8,37)$ і загальної конфліктності $(\mathrm{Mx}=21,87)$. 
Таблищя 3

Динаміка особистісної агресивності й конфліктності підлітків вибіркової сукупності

\begin{tabular}{|c|c|c|c|c|c|}
\hline Вікові групи & \begin{tabular}{|l|}
11 років \\
$(\mathrm{N}=43)$ \\
\end{tabular} & \begin{tabular}{|c|}
12 років \\
$(\mathrm{N}=123)$ \\
\end{tabular} & \begin{tabular}{|l|}
13 років \\
$(\mathrm{N}=103)$ \\
\end{tabular} & $\begin{array}{l}14 \text { років } \\
(\mathrm{N}=108)\end{array}$ & $\begin{array}{l}15 \text { років } \\
(\mathrm{N}=55)\end{array}$ \\
\hline $\begin{array}{l}\text { особистісної } \\
\text { агресивності й } \\
\text { конфліктності }\end{array}$ & \multicolumn{5}{|c|}{ Середні величини (Mx) } \\
\hline Запальність & 5,31 & 5,18 & 5,54 & 4,12 & 4,17 \\
\hline Наступальність & 4,81 & 4,91 & 4,04 & 4,24 & 3,83 \\
\hline Уразливість & 5,19 & 4,45 & 4,58 & 3,00 & 3,50 \\
\hline Непоступливість & 3,37 & 4,76 & 3,46 & 3,28 & 4,17 \\
\hline Безкомпромісність & 6,69 & 6,51 & 7,50 & 8,48 & 8,17 \\
\hline Мстивість & 4,56 & 4,61 & 3,71 & 3,00 & 3,83 \\
\hline Нетерпимість & 4,12 & 3,61 & 3,42 & 2,68 & 2,50 \\
\hline Підозріливість & 4,62 & 4,57 & 4,58 & 3,76 & 4,17 \\
\hline $\begin{array}{l}\text { Позитивна } \\
\text { агресивність }\end{array}$ & 7,69 & 9,67 & 7,37 & 7,68 & 9,00 \\
\hline $\begin{array}{l}\text { Негативна } \\
\text { агресивність }\end{array}$ & 8,37 & 8,27 & 6,79 & 5,64 & 5,83 \\
\hline Конфліктність & 21,87 & 20,30 & 21,87 & 19,40 & 20,00 \\
\hline
\end{tabular}

Досить складним у генезі особистісного буття підлітків є також період 12 років, означений максимумом виявлення Мх таких змістових характеристик особистісної агресивності, як наступальність $(\mathrm{Mx}=4,9091)$, непоступливість $(\mathrm{Mx}=4,76)$ і мстивість $(\mathrm{Mx}=4,61)$. Проте вектор агресивності 12-річних підлітків має позитивне спрямування $(\mathrm{Mx}=9,67)$, що зумовлює готовність до компромісу у вирішенні конфліктних ситуацій (безкомпромісність як параметр особистісної агресивності у цій віковій групі виявляється мінімально $(\mathrm{Mx}=6,51)$ порівняно з іншими віковими групами). 
Особливим смисловим акцентом профілю конфліктності підлітків 13 років є високий рівень (максимальні показники Мx) запальності $(\mathrm{Mx}=5,54)$ і загальна конфліктність $(\mathrm{Mx}=21,87)$ респондентів цієї вікової групи.

Найбільш адаптивною (безконфліктною), згідно з даними психодіагностичного вимірювання, є поведінка підлітків 14 років, профіль особистісної конфліктності яких відзначений максимумом кривої динаміки безкомпромісності. Інші параметри симптомокомплексу конфліктності (у тому числі й вектор загальної конфліктності) у системі особистісних конструктів 14-річних підлітків представлені мінімально. Нейтральним є також персонологічний профіль конфліктності підлітків 15 років: мінімально вираженими виявилися такі параметри, як наступальність $(\mathrm{Mx}=3,83)$ і нетерпимість $(\mathrm{Mx}=2,50)$; максимальні показники Мх у структурі симптомокомплексу агресивності та конфліктності 15-річних підлітків відсутні.

Однофакторний дисперсійний аналіз засвідчив статистично достовірні значущі відмінності між Мх у різних вікових групах підлітків за такими параметрами, як уразливість $(0,007$ при $p \leq 0,05)$, мстивість $(0,017$ при $p \leq 0,05)$ і негативна агресивність $(0,007$ при $p \leq 0,05)$. Підтвердження статистичної значущості відмінностей елементів структури симптомокомплексу особистісної агресивності та конфліктності у вікових групах підлітків забезпечив непараметричний (ранговий) односторонній дисперсійний аналіз Краскела - Волліса, який дає змогу перевірити відмінності між віковими групами підлітків за рівнем вираження досліджуваної ознаки. Установлено, що рівень вираження уразливості $(0,014$ при $p \leq 0,05)$, непоступливості $(0,025$ при $p \leq 0,05)$, безкомпромісності $(0,003$ при $p \leq 0,05)$ і мстивості $(0,003$ при $p \leq 0,05)$ у різних вікових групах підлітків статистично достовірно відрізняється. Крім того, підлітки на різних етапах дорослішання демонструють статистично достовірно різний рівень розвитку позитивної $(0,049$ при $p \leq 0,05)$ і негативної $(0,001$ при $p \leq 0,05)$ агресивності. 
Рівень виявлення інших параметрів симптомокомплексу особистісної агресивності та конфліктності у різних вікових групах підлітків статистично значуще не відрізняється (при $p>0,05)$.

Співставлення результатів психодіагностичного вимірювання змістових характеристик персонологічного профілю конфліктності підлітків різної статі обумовило виявлення основних тенденцій цієї змінної у площині міжстатевої диференціації підлітків (табл. 4.).

Таблиия 4

Міжстатеві відмінності середніх величин особистісної агресивності й конфліктності підлітків вибіркової сукупності

\begin{tabular}{|c|c|c|c|c|}
\hline \multirow{2}{*}{$\begin{array}{l}\text { Критерії } \\
\text { аналізу } \\
\text { мара- } \\
\text { особистісно } \\
\text { агресивності й } \\
\text { конфліктності }\end{array}$} & \multicolumn{2}{|c|}{ Хлопці (N = 247) } & \multicolumn{2}{|c|}{ Дівчата (N = 185) } \\
\hline & $\begin{array}{c}\text { Середне } \\
\text { (Mx) }\end{array}$ & $\begin{array}{l}\text { Стандартне } \\
\text { відхилення }\end{array}$ & $\begin{array}{c}\text { Середнс } \\
\text { (Mx) }\end{array}$ & $\begin{array}{l}\text { Стандартне } \\
\text { відхилення }\end{array}$ \\
\hline Запальність & 5,03 & 2,01 & 4,86 & 2,19 \\
\hline Наступальність & 4,83 & 2,06 & 3,81 & 1,95 \\
\hline Уразливість & 4,24 & 2,22 & 4,11 & 1,90 \\
\hline Непоступливість & 4,04 & 2,26 & 3,51 & 2,05 \\
\hline Безкомпромісність & 7,25 & 2,38 & 7,49 & 2,09 \\
\hline Мстивість & 4,28 & 1,97 & 3,38 & 1,78 \\
\hline Нетерпимість & 3,48 & 1,84 & 3,13 & 1,75 \\
\hline Підозріливість & 4,43 & 2,02 & 4,24 & 1,75 \\
\hline $\begin{array}{l}\text { Позитивна } \\
\text { агресивність }\end{array}$ & 8,82 & 3,75 & 7,40 & 3,46 \\
\hline $\begin{array}{l}\text { Негативна } \\
\text { агресивність }\end{array}$ & 7,64 & 3,31 & 6,32 & 2,69 \\
\hline Конфліктність & 20,55 & 4,54 & 20,89 & 4,71 \\
\hline
\end{tabular}


У поведінковому профілі конфліктності підлітківхлопців найбільш вираженими є такі характеристики, як безкомпромісність ( $\mathrm{Mx}=7,25$, I рангова позиція), запальність ( $\mathrm{Mx}=5,03$; II рангова позиція), що узгоджується 3 імпульсивним характером реагування хлопців у суперечливих ситуаціях. Активно виявляються підлітками-хлопцями і такі параметри особистісного профілю, як наступальність $(\mathrm{Mx}=4,83)$ і підозріливість $(\mathrm{Mx}=4,43)$, що засвідчує суперечливий характер міжособистісних інтеракцій. Найменш вираженою характеристикою підлітків окресленої соціальної групи є нетерпимість $(\mathrm{Mx}=3,48)$, що може інтерпретуватися як відкритість хлопців-підлітків амбівалентному досвіду, толерантність життєвої позиції у несталих соціокультурних умовах суспільства епохи постмодернізму.

Профіль конфліктності дівчат підліткового віку відзначається тотожними тенденціями: на першому плані особистісних характеристик зафіксовано безкомпромісність ( $\mathrm{Mx}=7,49$, I рангова позиція) і запальність $(\mathrm{Mx}=4,86$; II рангова позиція), що підтверджує імпульсивність підлітків незалежно від статевої приналежності. Привертає увагу в симптомокомплексі особистісної конфліктності дівчатпідлітків досить високий рівень вираження підозріливості $(\mathrm{Mx}=4,24)$ та уразливості $(\mathrm{Mx}=4,11)$, що може спричиняти деструктивні реакції дівчат у системі полісуб'єктної взаємодії. Прояви нетерпимості в особистісному профілі дівчат, як і у хлопців, мають найменший рівень прояву $(\mathrm{Mx}=3,13)$.

Співставлення середніх величин позитивної та негативної агресивності підлітків різної статі вказує на переважання позитивної агресивності (показники дещо вищі у підлітків-хлопців), виявлення загальної конфліктності відносно більш виражене у профілі агресивності дівчат ( $\mathrm{Mx}=20,89$ порівняно з $\mathrm{Mx}=20,55$ у підлітків-хлопців).

Загалом відмінності симптомокомплексів агресивності й конфліктності підлітків різної статі є відносними, що 
свідчить про тотожність особистісних профілів школярів цієї вікової групи. Це підтверджують дані статистичного аналізу із застосуванням t-критерію Стьюдента для порівняння незалежних вибірок. Установлено статистичну значущість відмінностей між групами підлітків різної статі у виявленні наступальності $(0,015$ при $p \leq 0,05)$ і мстивості $(0,022$ при $p \leq 0,05)$ як елементів персонологічного профілю конфліктності. Рівень вираження цих ознак у підлітків різної статі має позитивний вектор спрямування, а отже, є статистично достовірно вищим у вибірці хлопців підліткового віку ( $\mathrm{t}=2,47 \mathrm{i} \mathrm{t}=2,32$ відповідно). Крім того, статистично значущі відмінності між підлітками різної статі існують у виявленні негативної агресивності (0,041 при $p \leq 0,05$ i $t=2,07)$, що більш виражена в особистісному профілі хлопців.

Кореляційний аналіз із застосуванням коефіцієнта рангової кореляції rs Спірмена не виявив статистично значущого зв'язку між статевими відмінностями респондентів і показниками особистісної конфліктності підлітків. Спостереження за поведінковими сценаріями школярів підліткового віку та результати експертних оцінок учителями шкіл поведінкових сценаріїв підлітків вибіркової сукупності підтвердили відсутність суттєвих міжстатевих відмінностей у поведінці підлітків.

\section{Висновки}

Результати теоретичного аналізу проблемного поля виявлення деструктивної поведінки підлітків доводять, що поведінкові стратегії особистості формуються упродовж життя і є результатом взаємодії вимірів соціокультурного середовища, особистісних чинників та активності самої людини. Значущість цих чинників на різних етапах онтогенезу змінюється; у підлітковому віці особистісне становлення відбувається переважно у контекстуальному профілі генези персонологічних конструктів. Особистісні харак- 
теристики підлітків детермінують поведінкові сценарії, зокрема - сценарії конфліктної поведінки.

Багато підлітків у процесі міжособистісного спілкування виявляють імпульсивність, нестриманість в емоціях, низький рівень самоконтролю й поведінкової культури. Найбільш значущими особистісними характеристиками персонологічного профілю конфліктності підлітків є безкомпромісність, запальність, наступальність і непоступливість, що спричиняє деструктивні моделі поведінки.

Водночас дані емпіричного дослідження стратегій поведінки у конфліктних ситуаціях і персонологічного профілю конфліктності школярів підліткового віку доводять, що у процесі дорослішання поведінка підлітків різних вікових груп статистично достовірно не відрізняється. Відсутні суттєві відмінності також і у симптомокомплексі конфліктності підлітків різної статі.

Підлітки у конфліктних ситуаціях руйнують психологічну рівновагу опонентів і самостверджуються за їх рахунок, що пояснюється відсутністю досвіду конструктивної поведінки й навичок діалогічної комунікації. Конфліктність підлітків часто є результатом нездатності школярів довести свою думку засобами соціально прийнятної форми комунікації - діалогу, що дає підстави припустити дефекти соціального розвитку підлітків (наявність власного травматичного досвіду, приклади жорстокого поводження у сім’ї тощо). У контексті означеного не викликає сумніву необхідність психолого-педагогічної корекції деструктивних поведінкових патернів підлітків шляхом формування комунікативної культури особистості, засвоєння конструктивних стратегій спілкування. Розвиток особистості у період дорослішання має відбуватися через збагачення і перетворення суб'єктивного досвіду як важливого джерела оптимальної адаптації у ситуації невизначеності. Проте недостатність навичок моделювання необхідних поведінкових сценаріїв у індивідуальному досвіді підлітка детермінує проблемність об’єктивації стратегій життєтворчості 
у реальному житті підлітка. Підлітки (особливо - молодші підлітки) не навчені прийомам діалогічної комунікації, що характеризується орієнтацією на рівноправне спілкування, засноване на взаємній повазі й довірі; для них складно відстоювати у суперечках свою точку зору соціально прийнятними способами, що спричиняє хвилі агресії й прояв конфліктності.

Результати вивчення означеної проблеми та досвід корекційно-розвивальної діяльності дозволяють стверджувати, що моделювання оптимальних особистісних конструктів у підлітковому віці можливе лише у контексті набуття персонального досвіду успішної раціонально-конструктивної поведінки.

У результаті систематичного стимулювання (комунікативного моделювання) поведінкових сценаріїв підлітків відбувається перебудова індивідуального пізнавального досвіду, що призводить до появи індивідуально значущих життєвих сценаріїв особистості у парадигмах смислової реальності. Лише цілеспрямована соціально-психологічна стимуляція й оптимальне підкріплення адекватних вчинків особистості забезпечить формування у школярів підліткової групи необхідної установки на реалізацію адаптивних моделей поведінки, формування і закріплення у життєвому сценарії адекватної ситуації моделі поведінки. Комунікативне моделювання конструктивного особистісного профілю у контексті психолого-педагогічного супроводу суб'єктів освітнього простору має відповідати базовим стратегічним принципам гуманізації освіти:

- акцент на ресурсах особистості, врахування індивідуальних можливостей та особливостей поведінки;

- аналіз попереднього досвіду, світогляду, інтересів особистості;

- нетеоретичне, нестандартизоване бачення проблеми й спирання на суб'єктивну віру особистості у власні можливості; 
- приклади співробітництва і відкритості у стосунках між усіма суб'єктами навчально-виховного процесу;

- технічна пластичність, володіння необхідними знаннями й уміннями психологічної допомоги особистості.

Ефективними психотехніками соціально-психологічного впливу на особистісний профіль підлітків є методи дебатів і дискусійного аналізу проблемних ситуацій, що підсилюють (або активують) вплив інтелекту на поведінку . Реалізація означених принципів у системі психологічного супроводу особистості в закладах освіти дасть змогу якісно змінити ефективність особистісного розвитку та форматування поведінкових сценаріїв особистості.

Здійснений аналіз не вичерпує усіх аспектів порушеної проблеми. Отримані дані можуть бути покладені в основу подальшої дослідницької роботи з визначення шляхів оптимізації поведінкових сценаріїв підлітків.

\section{Література}

Білик Н. М. Соціально-педагогічна технологія медіаторства у вирішенні конфліктів між молодшими підлітками: автореф. дис. ... канд. пед. наук: 13.00.05. Київ, 2017. 20 с.

Бочавер А. А., Хломов К. Д. Буллинг как объект исследований и культурный феномен. Психология. Журнал Высшей школь эконоли$\kappa u$. 2013. № 10 (3). С. 149-159.

Ващенко І. В., Іваненко Б. Б. Психологічні ресурси особистості в подоланні складних життєвих ситуацій. Проблели сучасної психологї: Збірник наукових праць Кал'янець-Подільського національного університету ілені I. Огієнка, Інституту психологї ілені Г. С. Костюка НАПН України / За наук. ред. С. Д. Максименка, Л. А. Онуфрієвої. Кам'янець-Подільський : Аксіома, 2018. Вип. 40. С. 33-50.

Гіренко С. П. Формування конфліктологічної культури особистості в контексті трансформації її самосвідомості. Вісник Національного університету оборони Украӥни. Питання педагогіки. 2014. № 3 (46). C. 59-64.

Жаарова Д. В., Терех Е. Ю. Психологические особенности подросткового буллинга. Научно-педагогическое обозрение. Pedagogical Review. 2018. № 1 (19). C.102-116. DOI 10.23951/2307-6127-2018-1-79-84. 
Леонов Н. И. Психология конфликтного поведения: дис. ... д-ра психол. наук: 19.00.05. Ярославль, 2002. 415 с.

Лисенко О. М. Конфліктна поведінка особистості за умов трансформації українського суспільства: автореф. дис. ... канд. соціол. наук: 22.00.01. Харків, 2002. 20 с.

Резнікова О. А., Солодка О. В. Психологічні особливості поведінки підлітків у конфліктних ситуаціях. Теорія і практика сучасної пси хологї. 2018. № 2. С. 168-172.

Свириденко И. Н. Конфликтность личности с разными уровнями зрелости: автореф. дис. ... канд. психол. наук: 19. 00. 01. Екатеринбург, 2007. 23 с.

Токарева Н. Вариативностьличностного развития подростков в условиях реформирования образовательного пространства. Psychologiczne Zeszyty Naukowe. Człowiek $w$ całokształcie zycia: rodzina - edukacja-praca. Zielona Góra, 2018. № 1. C. 35-48.

Токарева Н. М. Психологія комунікативного моделювання особистісних конструктів у підлітковому віці: дис. ... д-ра психол. наук: 19.00.07. Київ, 2015. 530 с.

Ульянова Т. Ю. Індивідуально-психологічні особливості конфліктності як властивості особистості: дис. ... канд. психол. наук: 19.00.01. Одеса, 2017. 256 с.

Шамне А. В. Теорія та практика психосоціального розвитку у підлітково-юнацькому віці: монографія. Київ : ТОВ ВНП «Інтерсервіс», 2015. 488 c.

Bandura, A. (1978). The self system in reciprocal determinism. American Psychologist, 3, 356-357.

Bochaver, A. A., Zhilinskaya, A. V., \& Khlomov, K. D. (2015). School Bullying and Teachers' Attitudes. Social Psychology \& Society, 6, Issue $1,100-113$.

Olweus, D. (1993). Bullying at School: What We Know and What We Can Do (Understanding Children's Worlds). Oxford : Blackwell Publishing. P. 152.

\section{References}

Bilyk, N. M. (2017). Sotsialno-pedahohichna tekhnolohiia mediatorstva u vyrishenni konfliktiv mizh molodshymy pidlitkamy [Social-pedagogical technology of mediatorism in solving conflicts between younger teens]. Extended abstract of candidate's thesis. Kyiv [in Ukrainian].

Bochaver, A. A., \& Hlomov, K. D. (2013). Bulling kak objekt issledovanij i kul'turnyj fenomen [Bulling as an object of research and a cultural phenomenon]. Psihologija. Zhurnal Vysshej shkoly jekonomiki-Psychology. Journal of a higher school of economics, 10 (3), 149-159 [in Russian]. 
Vashchenko, I. V., \& Ivanenko, B. B. (2018). Psykholohichni resursy osobystosti v podolanni skladnykh zhyttievykh sytuatsii [Psychological resources of the personality in overcoming difficult life situations]. Problemy suchasnoi psykholohii - Problems of modern psychology: Collection of research papers of Kamianets-Podilskyi National Ivan Ohiienko University, G. S. Kostiuk Institute of psychology of NAES of Ukraine, 40, 33-50. Kamianets-Podilskyi : Aksioma [in Ukrainian].

Hirenko, S. P. (2014). Formuvannia konfliktolohichnoi kultury osobystosti $\mathrm{v}$ konteksti transformatsii yii samosvidomosti [Formation of the conflictological culture of the individual in the context of transformation of his consciousness]. Visnyk Natsionalnoho universytetu oborony Ukrainy. Pytannia pedahohiky - Newsletter of the National Defense University of Ukraine. Issues on Pedagogy, 3 (46), 59-64 [in Ukrainian].

Zharova, D. V., \& Tereh, E. Ju. (2018). Psihologicheskie osobennosti podrostkovogo bullinga [Psychological features of teenage bullying.]. Nauchno-pedagogicheskoe obozrenie - Pedagogical Review, 1 (19), 102-116. DOI 10.23951/2307-6127-2018-1-79-84 [in Russian].

Leonov, N. I. (2002). Psihologija konfliktnogo povedenija [Psychology of Conflict Behavior]. Doctor's thesis. Jaroslavl' [in Russian].

Lysenko, O. M. (2002). Konfliktna povedinka osobystosti za umov transformatsii ukrainskoho suspilstva [Conflict behavior of the individual in the conditions of transformation of Ukrainian society]. Extended abstract of candidate's thesis. Kharkiv [in Ukrainian].

Reznikova, O. A., \& Solodka, O. V. (2018). Psykholohichni osoblyvosti povedinky pidlitkiv u konfliktnykh sytuatsiiakh [Psychological peculiarities of behavior of adolescents in conflict situations]. Teoriia $i$ praktyka suchasnoi psykholohii - Theory and practice of modern psychology, 2, 168-172 [in Ukrainian].

Sviridenko, I. H. (2007). Konfliktnost' lichnosti s raznymi urovnjami zrelosti [Personality conflict with different levels of maturity]. Extended abstract of candidate's thesis. Jekaterinburg [in Russian].

Tokareva, N. (2018). Variativnost' lichnostnogo razvitija podrostkov v uslovijah reformirovanija obrazovatel'nogo prostranstva [Variability of the personal development of adolescents in the context of reforming the educational space]. Psychologiczne Zeszyty Naukowe. Czlowiek $w$ caloksztalcie zycia: rodzina - edukacja - praca. Zielona Gora, 1, 35-48 [in Russian].

Tokareva, N. M. (2015). Psykholohiia komunikatyvnoho modeliuvannia osobystisnykh konstruktiv u pidlitkovomu vitsi [Psychology of communicative modeling of personality constructs in adolescence]. Doctor's thesis. Kyiv [in Ukrainian].

Ulianova, T. Yu. (2017). Indyvidualno-psykholohichni osoblyvosti konfliktnosti yak vlastyvosti osobystosti [Individual psychological pecu- 
liarities of conflict as property of personality]. Candidate's thesis. Odesa [in Ukrainian].

Shamne, A. V. (2015). Teoriia ta praktyka psykhosotscialnoho rozvytku $u$ pidlitkovo-iunatskomu vitsi [Theory and practice of psychosocial development in adolescent age]. Kyiv : TOV VNP «Interservis» [in Ukrainian].

Bandura, A. (1978). The self system in reciprocal determinism. American Psychologist, 3, 356-357.

Bochaver, A. A., Zhilinskaya, A. V., \& Khlomov, K. D. (2015). School Bullying and Teachers' Attitudes. Social Psychology \& Society, 6 (1), 100-113.

Olweus, D. (1993). Bullying at School: What We Know and What We Can Do (Understanding Children's Worlds). Oxford : Blackwell Publishing.

\section{Токарева Наталя. Психологічний контент конфліктної поведінки підлітків}

\section{АНОТАЦІЯ}

У статті представлено результати дослідження психологічного контенту деструктивної поведінки підлітків у вимірах несталого інформаційного суспільства. Доведено, що в умовах прискорення темпів сучасної історії, розбудови інформаційного суспільства виникає потреба переосмислення суб'єктивних індикаторів особистісного дорослішання дитини. Констатовано, що акценти змішуються у напрямах розвитку критичного мислення, творчої винахідливості, креативності, самостійності, гнучкості утворення логічних схем поведінки. Найбільш значущим надбанням особистісного розвитку дитини в епоху інформаційного прогресу визнано навички вибудовування конструктивних мінособистісних стосунків.

Автором стверджується, що найчутливішими до мінливості соціального середовища є підлітки, серед яких на тлі проявів вікової кризи розвитку зростають ризики деструктивних, зокрема - конфліктних, форм поведінки. Зафіксовано значення змістовних характеристик особистості підлітків у розвитку конфліктів. Доведено, що конфліктна поведінка школярів у період дорослішання набуває ознак інструментальної агресії, є своєрідним різновидом захисту від неповаги до особucmocmi.

Автором наведено результати дослідження стилів поведінки сучасних підлітків у конфліктних ситуаціях. Емпіричним иляхом було досліджено змістову структуру персонологічного профілю конфлікт- 
ності й агресивності підлітків. З’ясовано, що найбільш значущими особистісними характеристиками симптомокомплексу агресивності та конфліктності підлітків є безкомпромісність і запальність; у виявленні комплексу агресивності переважає позитивна агресивність, показниками якої є такі особливості поведінки, як наступальність і непоступливість.

Зроблено висновок, що метою підліткової конфліктності переважно є порушення психологічної рівноваги опонентів і самоствердження, що пояснюється відсутністю досвіду конструктивної поведінки й навичок діалогічної комунікації. Констатовано, що моделювання оптимальних особистісних конструктів у підлітковому віці можливе лише у контексті набуття персонального досвіду успішної раціонально-конструктивної поведінки і підвищення психологічної культури діалогічного партнерства.

Ключові слова: підліток, особистісний профіль, психологічний ресурс, конфліктність, конфліктна поведінка, поведінкова стратегія, конфліктна ситуація.

\section{Токарева Наталья. Психологический контент конфликтного пове- дения подростков}

\section{АННОТАЦИЯ}

В статье представлены результаты исследования психологического контента деструктивного поведения подростков в измерениях нестабильного информационного общества. Доказано, что в условиях ускорения темпов современной истории, развития информационного общества возникает необходимость переосмысления субъективных индикаторов личностного взросления ребенка. Констатировано, что акценты смещаются в направлениях развития критического мышления, творческой изобретательности, креативности, самостоятельности, гибкости образования логических схем поведения. Наиболее значимым достоянием личностного развития ребенка в эпоху информационного прогресса признано навыки выстраивания конструктивных межличностных отношений.

Автор утверждает, что наиболее чувствительными к изменчивости социальной среды являются подростки, среди которых на фоне проявлений возрастного кризиса развития возрастают риски деструктивных, в частности - конфликтных, форм поведения. Зафиксировано значение содержательных характеристик личности подрост- 
ков в развитии конфликтов. Доказано, что конфликтное поведение школьников в период взросления приобретает признаки инструментальной агрессии, является своеобразной разновидностью защиты от неуважения кличности.

Эмпирическим путем было исследовано содержательную структуру персонологического профиля конфликтности и агрессивности подростков. Установлено, что наиболее значимыми личностными характеристиками симптомокомплекса агрессивности и конфликтности подростков является бескомпромиссность и вспыльчивость; в проявлениях комплекса агрессивности преобладает положительная агрессивность, показателями которой являются такие особенности поведения, как наступательность и неуступчивость.

Сделан вывод, что целью подростковой конфликтности преимущественно являются нарушение психологического равновесия оппонентов и самоутверждение, что объясняется отсутствием опыта конструктивного поведения и навыков диалогической коммуникации. Констатировано, что моделирование оптимальных личностных конструктов в подростковом возрасте возможно лишь в контексте приобретения персонального опыта успешного рационально-конструктивного поведения и повышения психологической культуры диалогического партнерства.

Ключевые слова: подросток, личностный профиль, психологический ресурс, конфликтность, конфликтное поведение, поведенческая стратегия, конфликтная ситуация. 